Pamiętnik Literacki 2021, 2, s. 181-193

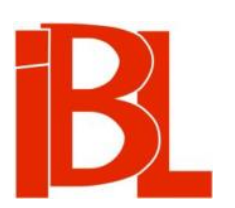

\title{
Gatunkowe obrazy świata: sielanka, litania, sonet
}

\author{
Witold Sadowski
}




\title{
Z A G A D N I E I A J E Z Y K A A R T Y S T Y C Z N E G O
}

\author{
Pamiętnik Literacki CXII, 2021, z. 2, PL ISSN 0031-0514
}

DOI: $10.18318 / \mathrm{pl} .2021 .2 .13$

WITOLD SADOWSKI Uniwersytet Warszawski

\section{GATUNKOWE OBRAZY ŚWIATA: SIELANKA, LITANIA, SONET}

Spróbujmy rozważyć gatunek jako wielką jednostkę semantyczną, która implikuje określony obraz świata.

Hipoteza wiążąca rozgraniczenia gatunkowe $z$ modelowaniem rzeczywistości nie jest oczywiście nowa. W kierunku takiej koncepcji zdawała się zmierzać Stefania Skwarczyńska, gdy pisała, że rodzaje literackie stanowią konsekwencję postrzegania wydarzeń życia jako pewnych stałych i powtarzalnych sytuacji. Nie trzeba też przypominać, że korelacja między ewolucją powieści a czasoprzestrzennym uporządkowaniem świata ilustrowała Bachtinowskie pojęcie chronotopu. Kwestia stosunku do rzeczywistości była wreszcie poruszana w monograficznych opracowaniach poszczególnych konwencji gatunkowych. Przypominają się prace Władimira Proppa, piszącego w kontekście bajki zwierzęcej o „światopoglądzie totemicznym" i wiążącego genezę eposu $\mathrm{z}$ krystalizacją idei narodu ${ }^{1}$.

Gatunek jako projekt umiejscowienia człowieka w naturze i społeczeństwie rozpatrywano przy charakteryzowaniu zjawisk tak różnych od siebie formalnie, historycznie i kulturowo, jak starogrecka oda (gdzie - wedle słów Teresy Kostkiewiczowej - „typ wypowiedzi niejako automatycznie przywoływał stojący za nim sposób rozumienia ludzkiego i naturalnego uniwersum"), ballada romantyczna (będąca według Ireneusza Opackiego „gatunkiem poezji oskarżającej ustrój, obyczaj, cywilizację, społeczeństwo, wojnę, ślepotę żywiołów”), XIX-wieczna powieść (interpretowana przez Roberta Scholesa jako wyraz „stłumionego konfliktu chrześcijaństwa i kapitalizmu”), japońskie haiku (dla którego typowe miały być „afirmatywność, spokój, czułość, współczucie” - modalności wyliczane przez Beatę Śniecikowską) czy wreszcie tragedia, sielanka, litania, a nawet sonet, o czym będzie jeszcze mowa dalej$^{2}$. Wiek XX nie zostawił po sobie jednak spójnej koncepcji teoretycznej, udzielającej odpowiedzi na pytanie, czy z zasady każdy gatunek opiera się na jakichś

1 S. Sk k a r c zy ń s k a, Geneza i rozwój rodzajów literackich. W zb.: Polska genologia literacka. Red. D. O s t a s z ew s ka, R. C u d a k. Warszawa 2007, s. 53-59. - M. B a c h t in, Formy czasu iczasoprzestrzeni $w$ powieści. W: Problemy literatury i estetyki. Przeł. W. Grajewski. Warszawa 1982. - W. Prop p: Bajki zwierzęce. W: Nie tylko bajka. Wybór, przekł. D. Ulicka. Warszawa 2000, s. 205; Russkij gieroiczeskij epos. Wyd. 2, popr. Moskwa 1958, s. 32-34.

2 T. Kost ki ew i c zow a, wstęp w: Odaw poezji polskiej. Antologia. Oprac. T. Ko s t ki ew i c zow a. Wrocław 2009, s. VII. BN I 316. - I. O p a c ki, Ballada literacka-opis gatunku. W: I. O p a cki, Cz. Zg orzels ki, Ballada. Wrocław 1970, s. 80. - R. S c h ole s, Powieść jako paradygmat etyczny? Przeł. P. Czapliński. „Pamiętnik Literacki” 1992, z. 4, s. 193. - B. Śniecikowska, 
założeniach światopoglądowych. Nawet samo pojęcie gatunkowego obrazu świata, do którego zaraz przejdziemy, nie było znane poprzedniemu stuleciu, a być może nie było nawet uważane za potrzebne ${ }^{3}$.

Im bardziej wszelako literatura współczesna dojrzewa w latach, tym bogatszy staje się zasób utworów funkcjonujących w sytuacji słabiej lub mocniej zamierzonego nieporozumienia. Dotyczy ono nie tyle gatunków, pojmowanych jako repertuar nakazów i możliwości, i nie tyle ich kategoryzacji, wywodzącej się z tradycji retorycznej ${ }^{4}$, ile głębszego, bardziej fundamentalnego poziomu - ich zaplecza ideowego. Jest to zjawisko w swojej całości przez naukę nadal niespenetrowane i chociaż nie da się tego nadrobić pojedynczym artykułem, warto postawić kilka hipotez i poczynić wstępne założenia.

Jedno z proponowanych założeń zawiera się w określeniu „gatunkowy obraz świata” (dalej: GOS). W badaniach nad relacją wiążąca gatunek z projektowanym przezeń stosunkiem do rzeczywistości wolno mianowicie do pewnego stopnia (jak dalece, o tym za chwilę) czerpać inspirację $z$ teorii językowego obrazu świata (nazywanego w literaturze przedmiotu JOS-em). Można przede wszystkim przejąć ambiwalencję ujawniająca się w definicji kluczowego terminu „obraz świata”, który w duchu niemieckiej tradycji filozoficznej rozumiany bywa nie tylko jako Weltbild (czyli obraz polegający na odzwierciedleniu relacji czy mechanizmów rozpoznawanych w rzeczywistości przyrodniczo-społecznej), lecz także jako Lebensanschauung (czyli obraz w sensie idei czy wartości nadających sens ludzkiemu stosunkowi do życia) ${ }^{5}$. W badaniach nad JOS-em oba te aspekty współwystępują ${ }^{6}$ i podobnie należy też rozpatrywać GOS, wprowadzając jedynie kilka koniecznych poprawek.

Główna różnica polega na tym, że właściwości, które w gatunkowym obrazie świata przedstawiają się jako analogiczne do cech JOS-u, dają się zaobserwować nie w mikroskali, nie na poziomie semantyki leksykalnej i gramatycznej (nie w znaczeniach słów utworu i nie w sensach wynikających ze sposobu ich łączenia czy odmiany), lecz w makroskali, obejmującej całościową, wieloskładnikową semantykę danej konwencji. Posługując się znanym rozróżnieniem Émile’a Benveniste'a ${ }^{7}$, wypada powiedzieć, że GOS to bardziej sfera „znaczeniowości wypowiedzenia” niż

Haiku po polsku. Genologia w perspektywie transkulturowej. Torun 2016, s. 79. Zob. też T. Ko s tki ew i c zow a, Oda w poezji polskiej. Dzieje gatunku. Wrocław 1996, s. 35.

3 Termin ten zaproponowałem w artykule Fenomen narracji litanijnej wobec stereotypu gatunkowego litanii („Przestrzenie Teorii” t. $12\langle 2009\rangle$, s. 219), a następnie w książce Litania i poezja. Na materiale literatury polskiej od XI do XXI wieku (Warszawa 2011, s. 12-13).

4 Zob. M. Głow iń s ki, Gatunek literacki i problemy poetyki historycznej. W zb.: Proces historyczny w literaturze i sztuce. Red. M. J a ni o n, A. Pi o r u n ow a. Warszawa 1967, s. 44-47. - R. Kr zywy, Wprowadzenie do genologii retorycznej. W: Poezja staropolska wobec genologii retorycznej. Wprowadzenie do problematyki. Warszawa 2014.

5 Zob. J. Anu si ewi c z, Problematyka językowego obrazu świata w pogladach niektórych językoznawców i filozofów niemieckich XX wieku. W zb.: Językowy obraz świata. Red. J. B a r t m iń s ki. Lublin 1999. - D. K. N a u g le, Worldview: The History of a Concept. Grand Rapids 2002, s. 73-82, 86-88, 121-126, 152, 157-162.

$6 \quad$ Przykładem może być monografia Językowy obraz świata, gdzie dotyczy to większości artykułów w tomie.

7 É. Benveniste, Semiologia języka. Przeł. K. Falicka. W zb.: Znak, styl, konwencja. Wybór, wstęp M. Głowiński. Warszawa 1977, s. 33. 
„Znaczeniowości znaku”, podczas gdy w JOS-ie liczy się raczej „Znaczeniowość znaku” niż „Znaczeniowość wypowiedzenia”.

Z takim zastrzeżeniem można rozpatrywać w GOS-ie prawidłowości, które uprzednio zostały zauważone na poziomie języka. Ciekawym zjawiskiem wydaje się np. swoisty konserwatyzm formalny. „Swoisty” - ponieważ nie czyni on gatunku spóźnionym w stosunku do zmieniającej się rzeczywistości pozaliterackiej. Takie podejrzenie zostało wykluczone w klasycznej pracy Opackiego. Gatunek, jak dowodził badacz, pierwszy reaguje na pojawienie się „nowych warunków społeczno-politycznych" i to on w istocie staje się kołem zamachowym przeobrażeń literatu$\mathrm{ry}^{9}$. Konserwatyzm formalny przejawia się raczej w tym, że pisarzowi, który chce przyswoić owe „nowe warunki społeczno-polityczne” czy jakiekolwiek elementy zewnętrzne wobec dzieła, gatunek nie oferuje innych narzędzi niż dotychczasowe. Zachowuje się zatem podobnie jak język, ten bowiem na określenie zaskakującej go sytuacji nie zawsze i nie od razu wykształca nowe pojęcia, natomiast bardzo często przez całe stulecia poprzestaje na zasobach wcześniejszych. Przychodzi tu na myśl znany przykład leksyki astronomicznej z jej archaicznym obrazem ciał niebieskich chodzących po sklepieniu jak plemię koczowników.

Jeżeli jednak ów konserwatyzm bywa przez gatunek wewnętrznie pokonywany, to dzieje się to również podobnie jak w języku, wyprawiającym się w rejony nieodkryte przez ontologie $z$ arsenałem możliwości drzemiących $w$ jego potencjalnej naturze. Tak jak żadna epoka nie jest w stanie do cna zgłębić znaczeniowego bogactwa systemu językowego, tak też na żadnym etapie dziejów nie jest możliwe całkowite wyczerpanie zasobów gatunku. Nowe zadania literackie wzywają więc nie tylko do zobrazowania ukrytych zakamarków rzeczywistości pozatekstowej, lecz także - w ramach tej samej operacji odkrywania świata - wymuszają odsłonięcie nieznanych dotąd aspektów semantycznych zastosowanej konwencji. I tak jak język ściga rzeczywistość za pomocą metafor, które chcą przezwyciężać obustronną nieadekwatność słowa i świata, tak też można mówić o procesach swoistej metaforyzacji gatunkowej, kiedy na gruncie tragizmu czy wzniosłości kształtuje się, nie usuwając poprzedniego, nowe - metaforyczne właśnie - przedłużenie, pogłębienie lub rozszerzenie światopoglądowych założeń - odpowiednio - tragedii lub ody ${ }^{10}$.

Konserwatyzm obrazu świata to zatem cecha, która w GOS-ie powstaje i rozwija się według podobnych praw jak w JOS-ie. Drugą taką cechą wydaje się selektywność. Nietaktem wobec czytelnika byłoby streszczanie podstawowych rozważań

$8 \quad$ Z tego właśnie powodu A. Ka dy jew ska (Problematyka obrazu świata $w$ badaniach języka pisarza 〈na przykładzie pism Cypriana Norwida〉. W zb.: Semantyka tekstu artystycznego. Red. A. Pajdzińska, R. Tokarski. Lublin 2001) postawiła postulat, by teorię JOS-u rozszerzyć o koncepcję tekstowych obrazów świata.

9 I. O pa cki, Krzyżowanie się postaci gatunkowych jako wyznacznik ewolucji poezji. „Pamiętnik Literacki” 1963, z. 4, s. 382-383.

10 Do czynników oddziałujących metaforyzująco na GOS ody zaliczylibyśmy więc nowożytne rewizje pojęcia wzniosłości, o których pisze T. Ko stki ewi c zow a (Kilka uwag o wzniosłości. W: Oda $w$ poezji polskiej). O tym, że proces metaforyzacji założeń światopoglądowych gatunku nie może doprowadzić do utraty przekonania, iż jest to z grubsza ten sam obraz świata, można się przekonać czytając ksiażkę G. Stein e ra The Death of Tragedy (New York 1961, zwłaszcza s. 313, 319, 329-335, 341, 353). 
filozoficznych o języku, który jednocześnie daje dostęp do rzeczywistości i tego dostępu odmawia. Wystarczy powiedzieć, że również tutaj rysuje się analogia między GOS-em a JOS-em. Tak jak słowa ułatwiają konceptualizację kosmosu dzięki nazywaniu tylko nielicznych jego elementów, a pozostawieniu w sferze niedomówienia całej nieogarnionej reszty, tak też gatunek oferuje obraz świata w postaci zawsze uproszczonej. Analogia ta nie wyjaśnia wprawdzie wszystkich uwarunkowań zagłady gatunków w literaturze współczesnej, pozwala jednak dostrzec pozorny charakter ich rozpadu ${ }^{11}$, będącego częstokroć niczym więcej jak wynikiem przełączenia uwagi między dwoma zamiennymi dominantami. W pierwszej dominancie gatunek jest traktowany jako godny zaufania przewodnik po świecie, który oswaja rzeczywistość zaprowadzając w niej porządek, podczas gdy w drugiej dominancie (ujawniającej odwrotną stronę medalu) daje do zrozumienia, że nie ogarnia wymykającej się owemu zagospodarowaniu reszty. Jest to wszakże za każdym razem ta sama konwencja i ten sam GOS.

Wystarczy wymienionych przykładów na potwierdzenie, że gatunkowy obraz świata podpada pod prawidłowości typowe także dla JOS-u. Spróbujmy teraz odpowiedzieć na pytanie, w jakim stopniu to czyni.

Podstawowa różnica między GOS-em a JOS-em zdaje się polegać na tym, że treści semantycznych GOS-u, zaktualizowanych w utworze, nie da się w pełni zwerbalizować przy użyciu środków leksykalnych i gramatycznych wykorzystanych w tym samym dziele, służących do aktualizacji JOS-u. Gatunek zawsze wyrasta ponad język. Wprawdzie nie sposób go rozpoznać bez tekstu wypowiedzianego w jakimś języku, jednakże $z$ chwilą identyfikacji rozpoczyna on niejako życie na własną rękę, usamodzielniając się i sugerując czytelnikowi właściwy tylko sobie obraz świata. Wole przekroczenia języka uskutecznia na różne sposoby, a jednym $z$ ważniejszych wydaje się położenie większego nacisku na wizualny aspekt treści gatunkowych.

Obraz w JOS-ie zawsze funkcjonuje w sferze werbalizacji. Tego, co w nim przedstawione, bardzo często nie widzimy nawet „oczyma wyobraźni”. Zwykle jest to raczej lingwistyczny analogon i suplement świata niż jego mentalny wizerunek, ponieważ język, operując materiałem słownym, siłą rzeczy musi sprowadzać widzenie do myślenia pojęciami, nawet gdy nazywa przedmioty dające się zobaczyć.

$Z$ obrazem świata w GOS-ie jest inaczej. Gatunek może wywierać tak mocną sugestię wizualną, a zarazem wywoływać tak dojmujące poczucie jej nieuchwytności w mowie, że czasami domaga się wręcz przełożenia na sztalugi. Nie zawsze znajduje to rzeczywisty rezonans w sztukach pięknych. Zdarza się jednak i tak, że jego wykraczanie ponad język w kierunku tworu malarskiego prowadzi do powstawania trwałych materializacji artystycznych GOS-u.

Malarskie manifestacje gatunkowego obrazu świata zaznaczyły się np. z wyjątkową wprost wyrazistością w historii sielanki. Pierwotnie była to, jak wiadomo, forma literacka. Szkicując perspektywę życia pasterskiego, Wergiliusz posługiwał się kredką środków czysto językowych:

Szczęsny starcze, ty tu nad brzegami znajomych ruczajów

Będziesz u świętych strug cienistego chłodu zażywał. 
Tutaj ten sam co zawsze od granic sąsiednich żywopłot, Karmiąc pszczoły hyblejskie wierzbowych baziek okwiatem, Często łagodnym szelestem do drzemki znęci cię słodkiej.

Tutaj pod skały stromizną ogrodnik zaśpiewa po rosie, Gruchać zaś twoje pieszczotki, gołębie, będą - a z dala,

$Z$ koron wyniosłych drzew nie ustanie zawodzić turkawka ${ }^{12}$.

Obrazy te wyrażały jednak na tyle silną wolę powołania do życia nieograniczonej językowo panoramy, że prosiły się o potwierdzenie tej sugestii kreacyjną, orficką materializacją. Nic więc dziwnego, że wcześniej czy później musiało się to odzwierciedlić w narodzinach malarstwa pastoralnego. Mimo że przez kolejne wieki zmieniała się paleta stylów i technik artystycznych (ocean błota, który zatrzymał furmankę na słynnym płótnie Johna Constable’a, odsłania inne oblicze wsi niż, powiedzmy, Koncert wiejski Giorgionego, przedstawiający dwóch arystokratów między nimfami), bez trudu można rozpoznać w kompozycjach tego nurtu ciagłość sielankowej inspiracji, obejmującej zarówno sfere Weltbild (wiejski krajobraz, przyroda układająca się do spoczynku, ukazywana zawsze od bardziej pociagającej strony), jak i Lebensanschauung (wizja życia udanego, tchnącego spokojem, gdzie praca nie wykracza ponad ludzkie siły, a drobne utrapienia mają swój malowniczy urok).

W sztukach plastycznych dzieła nurtu pastoralnego nie funkcjonują w pełni autonomicznie. Gdybyśmy zdołali przeprowadzić niewykonalny w praktyce eksperyment, usuwając ze świadomości społecznej sielanke poetycką ze wszystkimi jej pozaliterackimi przedłużeniami w kulturze (łącznie ze współczesną myślą ekologiczna), a zostawiając jedynie malarstwo pastoralne, wówczas uderzyłaby nas w aspekcie Weltbild - nieadekwatność tych obrazów do naszej wiedzy, jak naprawdę wygląda lub wyglądało życie na wsi, a w aspekcie Lebensanschauung - zanik poczucia, że „sztuka tworzy nową nature”, że „zamiast zerkać tęsknie za starym rajem, wygląda nowego"13 i że „człowieka nie mogącego już wrócić do Arkadii prowadzi aż do Elizjum" ${ }^{14}$. Przeświadczenia te zostałyby zatracone, gdyż w malarstwie, pozbawionym substratu ideowego czerpanego $z$ poezji, przestałby być funkcjonalnie obecny „ponadczasowy projekt antropologiczny, wyrażający ludzką tęsknotę za [...] harmonią bytu oraz autentycznością uczuć i relacji międzyludzkich"15. To nie oznacza, rzecz jasna, że sceny pędzla Jana Steena, Nicolasa Poussina, Claude’a Lorraina, Louisa le Naina czy innych arkadyjskich wizjonerów należy ogląać z Wergiliuszem w ręku. Chodzi o to, że GOS sielanki, jeszcze przed zmaterializowaniem się w dziełach plastycznych, zdołał wykroczyć poza ramy semantyczne wyznaczane środkami leksykalno-gramatycznymi i wyzwolić się z ograniczeń JOS-u, by od tej pory - jako gatunkowy (w sensie literackim) obraz świata - współtworzyć „idyllę

Wergiliu sz, Ekloga I. W: Bukoliki i Georgiki. Wybór. Przeł., oprac. Z. Abramowiczówna. Wrocław 1953, s. 7, w. 51-58. BN II 83.

13 P. V. Marin elli, Pastoral. London - New York 2018, s. 22.

14 Słowa F. Schillera przytaczane przez A. W it k ow s ka (Stawianie, my lubim sielanki... Warszawa 1972, s. 71).

15 T. Kostki ewi czowa, Sentymentalizm - sielanka - długie trwanie. O nawiazaniach do sentymentalnych podstaw gatunku $w$ poezji XX wieku. „Rocznik Komparatystyczny - Comparative Yearbook" t. 9 (2018), s. 218. 
kultury" ${ }^{16}$. A dzieje się to z takim rozmachem, że potrafi mobilizować publiczność literacką do przypisywania treści GOS-u samej rzeczywistości zewnętrznej, tak jakby jego założenia poznawcze były nam dostarczane bezpośrednio przez przyrodę.

Niemała w tym zasługa pastoralnych ogrodów. Allan R. Ruff za przełomowy uznaje projekt posiadłości Mondragone w okolicach Rzymu, która na początku XVII wieku, gdy papieżem był Paweł V, została wszechstronnie przekształcona w swego rodzaju sielankowy mikrokosmos:

$Z$ willi położonej na wzgórzu lub z jej ogrodowego portyku papież, „papieski siostrzeniec” i goście mogli zanurzać wzrok w idyllicznym krajobrazie z wypasającymi się stadami owiec i kóz, trzodami bydła, pracownikami winnicy, pasterzami, rolnikami, gajami pełnymi drzew, plantacjami winorośli i halami. Widok na góry i morze ukazywał oglądającym dzikie moce natury, podkreślając w pastoralnym krajobrazie działanie harmonijnie uporządkowanych sił. Sama zaś willa z sylwetką Rzymu na horyzoncie przypominała o przeciwieństwie między miastem a wsią ${ }^{17}$.

Na zlecenie „papieskiego siostrzeńca”, kardynała Scipionego Caffarellego-Borghesego, przyjęcia w willi uświetniał recytacją swoich dzieł Lelio Guidiccioni, przedstawiający się jako poeta pasterz, dla którego posiadłość Mondragone miała stanowić współczesną Arkadię:

Guidiccioni dawał do zrozumienia, że zbocza Frascati zostały obrócone w ziemski raj z gajami strzeżonymi przez bóstwa i z niwami zaludnionymi przez towarzyszących pasterzom satyrów i faunów ${ }^{18}$.

Głos śpiewaka wspierały także inne sztuki:

Wizję zakładająca przekształcenie rzeczywistej posiadłości w idyllicznie poetycki, pastoralny krajobraz podkreślała zgromadzona przez Scipionego kolekcja malarstwa pejzażowego. $Z$ apartamentów książęcych, z których roztaczała się panorama na Kampanię, odwiedzający przechodzili do galerii ze starannie przemyślanymi punktami widokowymi. Na ścianach Scipione prezentował krajobrazy flamandzkie, martwe natury, scenki wiejskie i rodzajowe. Do sporządzenia fresków zatrudnił wiele wschodzących gwiazd malarstwa pejzażowego, takich jak Paul Brill i Agostino Tassi. Dzieła te wyposażały oglądających posiadłość w pastoralny szkic, który wspierał intelektualne wzloty fantazji. Mogli oni porównywać pejzaże i wymalowane przedstawienia wiejskiego życia z tym, co sami zobaczyli, spacerując po willi i ogrodzie ${ }^{19}$.

W kreacji sielankowego uniwersum niewątpliwą motywację przynosiły cele polityczne, utylitarne. Arkadyjska niewinność miała wzmacniać pożądany wizerunek rodu Borghese. W żaden sposób nie podważa to jednak skuteczności mechanizmów genologicznych, dzięki którym w ekosferze wiejskiej posiadłości zmaterializował się obraz świata wpisany w gatunek literacki.

Sielanka jest oczywiście konwencją szczególną, ale nie jedyną, która doczekała się uzewnętrznienia plastycznego. We wcześniejszej publikacji była już okazja dość obszernie omówić problematykę obrazu świata w innym ciekawym gatunku: litanii ${ }^{20}$. Litanijne wyliczenia, opierające się na charakterystycznym zestawianiu tego, co jest stałe i uporczywie powtarzalne, oraz tego, co $\mathrm{z}$ wezwania na wezwanie

A. R. Ru ff, Arcadian Visions: Pastoral Influences on Poetry, Painting and the Design of Landscape. Oxford 2015, s. 47.

18 Ibidem, s. 48.

19 Ibidem

20 Zob. W. Sa d ow s ki, Litania - gatunkowy obraz świata. W: Europejski wiersz litanijny. W innej czasoprzestrzeni. Warszawa 2018. 
ulega ciagłym zmianom, celowo utrzymują kryjącą się za nimi wizję kosmologiczną w stanie ledwie dostrzegalnego prześwitu, broniąc rozum przed intelektualnym zawłaszczeniem tajemnicy, którą swoją strukturą subtelnie objawiają. Ludzka potrzeba skupienia uwagi na nieco wyraźniejszym zarysie tej wizji znalazła jednak oparcie w reprezentacjach malarskich: w bizantyjskich mozaikach zdobiących sklepienia półkoliste i w gotyckich rozetach witrażowych. Dopiero w tych przedstawieniach widać jak na dłoni teocentryczną koncepcję czasoprzestrzeni wpisaną $\mathrm{w}$ litanię. Sumując wiedzę wynoszona z różnych dziedzin artystycznych, można lepiej zrozumieć, że ontologiczny ośrodek kosmosu, znajdujący się w Bogu i oddawany przez malarstwo za pomoca centralnie usytuowanego symbolu Zbawiciela, a w litanii przez aspekt powtarzalny wyliczeń, jest traktowany jako źródło nieskończonej różnorodności świata, ilustrowanej w malarstwie dzięki orbitalnemu rozmieszczeniu bytów wokół pola centralnego, w litanii zaś - dzięki składniowej zależności elementów zmiennych od elementu powtarzalnego.

W literaturze współczesnej ta gatunkowa czasoprzestrzeń ujawnia się sprofilowana przez którąś z dwóch wspomnianych biegunowych dominant, wynikających z selektywności GOS-u. Weźmy np. fragment utworu Ha sido dicho (Zostało powiedziane) Juana-Eduarda Cirlota, poety znanego polskim czytelnikom jako autor słownika symboli. Wiersz inspiruje się Hymnem trzech młodzieńców z biblijnej Księgi Daniela:

$$
\begin{aligned}
& \text { Alabad al Señor en las montañas. } \\
& \text { Alabad al Señor en los incendios. } \\
& \text { Alabad al Señor en los caminos. } \\
& \text { Alabad al Señor en las ciudades. } \\
& \text { Alabad al Señor en las murallas. } \\
& \text { Alabad al Señor en los océanos. }
\end{aligned}
$$

[Chwalcie Pana w górach. / Chwalcie Pana w otchłaniach. // Chwalcie Pana na drogach. / Chwalcie Pana w miastach. // Chwalcie Pana na murach. / Chwalcie Pana w oceanach. $]^{21}$

Podobną strukturę ma 8 kolejnych wersów poematu. W następującej potem części schemat wyliczenia ulega subtelnej zmianie:

$$
\begin{aligned}
& \text { Alabad al Señor de los olivos. } \\
& \text { Alabad al Señor de los cristales. } \\
& \text { Alabad al Señor de los leones. } \\
& \text { Alabad al Señor del horizonte. }
\end{aligned}
$$

[Chwalcie Pana drzew oliwnych. / Chwalcie Pana kryształów. // Chwalcie Pana lwów. / Chwalcie Pana horyzontu. $]^{22}$

Wyliczenie znowu kontynuuje się przez kilka wersów, by ponownie ulec transmutacji:

$$
\begin{aligned}
& \text { Alabad al Señor con grandes gritos. } \\
& \text { Alabad al Señor con alimentos. } \\
& \text { Alabad al Señor con frutas rojas. } \\
& \text { Alabad al Señor con trajes blancos. }
\end{aligned}
$$


[Chwalcie Pana wielkim wołaniem. / Chwalcie Pana ofiarami. // Chwalcie Pana kraśnymi owocami. / Chwalcie Pana białymi szatami. $]^{23}$

Gdy zaś w późniejszej części utworu na miejscu „con” zaczyna się powtarzać "como”, czytelnik uświadamia sobie wreszcie, że stał się świadkiem zobrazowania w strukturze wersów wspomnianej przed chwilą teocentrycznej wizji kosmosu. W samym centrum tego świata znajduje się Bóg, reprezentowany w wierszu przez niezmienność anafory „Alabad al Señor [Chwalcie Pana]”, rozciagającej się na przestrzeni 54 zawołań. Bezpośrednio z Bogiem stykaja się - jak gdyby na pierwszej orbicie wokół niego, wyselekcjonowane jak aniołowie - cztery niepozorne wyrazy: „en [w]”, „de [od]”, „con [z]” i „como [jak]”. Spełniają one skromną funkcję gramatycznych łączników, lecz w istocie urastają symbolicznie do rangi czegoś więcej niż tylko przyimek lub spójnik, gdyż dopiero po nich, na drugiej orbicie, w pewnym oddaleniu od Boga i poddane władzy któregoś z wyrazów pośredniczących, wyliczane jest w rzeczownikach nieprzebrane bogactwo rzeczywistości stworzonej: góry, oceany, kryształy, owoce, lwy itd.

Pozorne zaprzeczenie tej teocentrycznej wizji gatunkowej zawarł Henri Michaux w utworze Quelque part, quelqu'un (Gdzieś, ktoś). Tu również powtarza się anaforyczne centrum, na dużych obszarach tekstu widać zarysy anielskiej orbity wyrazów pośredniczących, a w zakończeniach wersów - nieskończone morze bytów, zjawisk i wydarzeń:

Quelqu'un, il a plus de fleuve que d'île
Quelqu'un il a plus de barrage que de fleuve
Guelqu'un il a plus d'horizon que de barrage
Quelqu'un, il a plus de savoir que d'horizon
[. . . . . . . . . . . . . . . . . . . . . . ]
Quelqu'un, pour lui le réveil est une pistache
Quelqu'un, pour lui le réveil est une tasse
Quelqu'un, pour lui l'éveil est une médecine
Quelqu'un, pour lui c'est une glaire
Quelqu'un, pour lui c'est un clou
Quelqu'un, pour lui le sommeil est un melon

[Ktoś, w kim jest więcej rzeki niż wyspy / Ktoś w kim jest więcej zapory niż rzeki / Ktoś w kim jest więcej widnokręgu niż zapory / Ktoś, w kim jest więcej wiedzy niż widnokręgu / [...] / Ktoś, dla kogo przebudzenie jest pistacją / Ktoś, dla kogo przebudzenie jest filiżanką / Ktoś, dla kogo pobudzenie jest medycyną / Ktoś, dla kogo jest ono białkiem 〈jajka〉 / Ktoś, dla kogo jest ono sednem / Ktoś, dla kogo sen jest melonem] ${ }^{24}$

Czytelnik jednak dość szybko zaczyna wątpić, czy kolejne elementy wyliczenia istotnie odsłaniają ustrukturyzowany mądrze porządek rzeczywistości:

\author{
Quelqu'un est pour les pulsions \\ Guelqu'un est pour le Mythe \\ Quelqu'un est pour le Matérialisme historique
}

[Ktoś jest dla popędów / Ktoś jest dla Mitu / Ktoś jest dla Materializmu Historycznego] ${ }^{25}$

Ibidem.

H. Michaux, Quelque part, quelqu'un. W: OEuvres complètes. Éd. R. Bellour, Y. Tran. T. 1. Paris 1998, s. 551. Interpunkcja oryginalna.

Ibidem, s. 553. 
W pewnym momencie, przy zachowaniu niezmiennej anafory, reszta wersów zamienia się w cybernetyczny czy onomatopeiczny bełkot: „Quelqu'un 000000000 01”, „Quelqu'un r r r r r...”, „Quelqu'un tchup... tchup... tchup...” itp. ${ }^{26}$ Może to wyglądać na rozpad litanijnej wizji świata, lecz w istocie ośmiesza tylko środki językowe próbujące tę wizję zwerbalizować. Ukazuje spektakularną klęskę JOS-u, chcacego w pełni wypowiedzieć GOS. Ten ostatni zachowuje natomiast tę samą ambiwalentną kondycję co w poprzednio przytaczanym utworze Cirlota. Oba wiersze mają w zapleczu jednakowy zarys relacji kosmologicznych. Widzimy go wszakże w innej dominancie - tam eksponującej zaufanie do gatunkowego modelu rzeczywistości, tu natomiast wysuwającej na pierwszy plan jego redukcjonistyczne uproszczenia.

Rozprawiając dużo na temat treści GOS-u odwołujących się do wyobraźni wzrokowej, braliśmy do tej pory pod uwagę kwestię obrazu w sensie dość bliskim znaczeniu potocznemu. Obraz jest czymś, co można zobaczyć - jeśli nie naocznie, to w marzeniach, w widzeniu wewnętrznym lub w objawieniu. Tymczasem wykraczanie gatunku poza jego podłoże językowe nie musi zmierzać w kierunku malarstwa potraktowanego jako ekspozycja proklamowanej przezeń wizji świata, pozwalająca wystawić na widok publiczny zakładane w niej stosunki przestrzenne. Dana konwencja może też ewokować obrazy muzyczne, wyzwalające potrzebę materializacji nie na sztalugach, lecz w dźwiękach. Dotyczy to m.in. litanii. W realizacjach kościelnych stanowi ona formę, której nie można czytać w dowolnym, wybranym przez siebie tempie. Śpiew zapewnia bowiem coś więcej niż tylko uroczysty charakter aktu religijnego czy harmonijne wykonanie przez wspólnotę. Melodia daje wiernym właściwy czas na przeżycie modlitwy, wyznacza optymalny rytm zanurzania się w litanijnym obrazie świata, dostarcza miar pozwalajacych uchwycić jego temporalne paradygmaty.

Spróbujmy zatem pokusić się o rozróżnienie wizualnych i audialnych wymiarów GOS-u. O ile malarstwo, mające naturalną tendencję do przejmowania i eksponowania wymiaru Weltbild, zdaje się sugerować, że konwencja sielanki czy litanii jest czymś w rodzaju fotografii przedstawiającej określone prawa przyrodnicze czy kosmologiczne, o tyle muzyka przychodzi z pomocą raczej wówczas, gdy gatunkowy światopogląd stanowi bardziej kwestię odczuwania niż widzenia. Wchodzi tu w grę nader niejasne i bardzo trudne do analizy naukowej, lecz silnie obecne w kulturze mniemanie, że pewne rodzaje muzyki są zdolne nastrajać człowieka do takiej czy innej postawy życiowej. Tak doświadczana muzyka staje się szczególnie predestynowana, by ujawniać w GOS-ie wymiar Lebensanschauung, być może na zasadzie udrażniania drogi w neuropsychologicznym sensie torowania ${ }^{27}$.

Nie da się zaprzeczyć, że sugestywność obrazu świata, zmagazynowana w sielance i znajdująca ujście w malarstwie pastoralnym, przebiła sobie także drugi kanał ekstrapolacji w postaci nurtu pastoralnego w muzyce. W najbardziej znanym tego przykładzie, VI Symfonii Ludwiga van Beethovena, pojawia się wiele melodycz-

27 Teorię torowania (w tym badania muzykologiczne $\mathrm{z}$ jej wykorzystaniem) referuję $\mathrm{w}$ artykule Prosodic Memory: Claudel - Eliot - Liebert (Przel. A. Kr e m e r. „Prace Filologiczne. Literaturoznawstwo" 2013, cz. 1, s. 13-16). 
nych przedstawień: „burza, będąca częścią tradycji muzycznych burz od Vivaldiego do Brittena, p ot o $\mathrm{k}$ z jego falującym akompaniamentem, słynne naśladowanie ptaków: słowika, przepiórki i kukułki" ${ }^{28}$. W tradycji sielanek orkiestrowych ważniejsza od mimetyzmu wydaje się jednak sama sfera dźwięku: „łagodne metrum siciliany 12/8 lub 6/8"29, cytaty z tańców ludowych, motywy pasterskich nawoływań, myśliwskiego rogu ${ }^{30}$, nade wszystko zaś instrumenty: flety i oboje ${ }^{31}$. Wergiliański poeta, który „na wątłej fletni się bawi”32, oglądany jako czołowa postać w idyllicznym pejzażu, był bowiem zarazem uważany za tego, który sam otwiera przed czytelnikiem drzwi do swojego świata dzięki muzyce wyczarowanej właśnie z owej „wątłej fletni”, a dzieła kompozytorów nowożytnych, takie jak La Pastorella Antonia Vivaldiego, Symfonia pastoralna Beethovena czy II Symfonia Johannesa Brahmsa $^{33}$, starały się różnorako tę kreacyjną orficką melodykę zmaterializować. Podobnie jak w wypadku malarstwa pastoralnego, wydostanie się poza sferę wypowiedzi językowej nie oznaczało jednak porzucenia literatury. Ich Lebensanschauung miała bowiem swoje stałe zakotwiczenie w gatunku literackim, bez którego we wspomnianych burzach i potokach przestałyby się ujawniać wydobywane z sielanki wartości. Ani „prawa czułego serca” ${ }^{34}$, ani perspektywa „życia wycofanego”, pojmowanego jako czas „wyzwolenia uczuć” lub jako azyl przed „społecznymi zawiłościami zbyt wielkimi, by je znosić" 35 , nie byłyby dostępne świadomości słuchaczy jako ważne składniki odbioru wspomnianych dzieł muzycznych.

Problematykę GOS-u zarysowaliśmy na przykładzie zaledwie dwóch gatunków. Kolejne badania powinny tę kwestię rozważyć szerzej, uwzględniając kompleksowy repertuar konwencji literackich. Szczególnie dużo uwagi powinno się poświęcić zjawiskom zdającym się zaprzeczać tezom artykułu. Należałoby zwłaszcza poddać analizie gatunki, których cechy definicyjne ograniczają się do wyznaczników czysto technicznych, niezwiązanych $\mathrm{w}$ żaden sposób $\mathrm{z}$ kreowaniem świata przedstawionego czy z wyjawianiem za jego pomocą takich czy innych założeń ideowych. Spróbujmy na koniec jedną $z$ takich form przeanalizować, zatrzymując się na krótką chwilę przy sonecie.

Sonet uchodzi współcześnie za konwencję, w której ramach da się powiedzieć praktycznie wszystko, która sprawdza się nieomal w każdej kulturze i którą można dowolnie obrabiać, byle została zachowana zasada 14 wersów $^{36}$. Jego wyjątkowa

R. M on e1le, The Musical Topic: Hunt, Military and Pastoral. Bloomington 2006, s. 243. Ibidem, s. 215.

Zob. F. E. Kirby, Beethoven's „Pastoral Symphony” as a „Sinfonia caracteristica”. „The Musical Quarterly" 1970, nr 4, s. 613.

Zob. Monelle, op. cit., s. 271.

Wergiliusz, op. cit., s. 1, w. 2.

Chcąc wykazać aktywność gatunku literackiego w kontekście dzieł czysto muzycznych, celowo odkładam na bok temat pastoralnych oper, oratoriów i pieśni, gdzie komponent literacki zostaje użyty bezpośrednio.

T. Kostkiewiczowa, O nowa normę intymności $w$ sielance. W: Model liryki sentymentalnej $w$ twórczości Franciszka Karpińskiego. Wrocław 1964, s. 67.

Zob. Marinelli, op. cit., s. 24.

Zob. W. M ö n c h, Das Sonett. Gestalt und Geschichte. Heidelberg 1955, s. 42-44. - A. D z i a d e k, Fenomen sonetu. W zb.: Różne głosy. Prace ofiarowane Stanisławowi Balbusowi na jubileusz siedemdziesięciolecia. Red. D. Woj da, M. Heyd el, A. Hej mej. Kraków 2013, s. 96-97. 
elastyczność rodzi wśród badaczy kontrowersje, czy jest to pełnoprawny gatunek, czy raczej układ stroficzny ${ }^{37}$. Rozważania w niniejszym artykule pozwalają, jak się wydaje, przeciąć ten spór i udzielić na zadane pytanie odpowiedzi salomonowej: dopóki struktura stroficzna ewokowała określony światopogląd, sonet miał status gatunku; z chwila utraty zakotwiczenia ideowego stał się jedynie wersyfikacyjnym wyzwaniem. Wprawdzie związana $z$ nim pierwotna wizja rzeczywistości nie wyrażała się w równie malowniczych kształtach jak w sielance i nie miała kosmicznego rozmachu litanii, ale też właśnie w tych różnicach uwidoczniała się jego zamierzona subtelność. Miał to być przecież nie suono, pełnobrzmiący dźwięk, lecz zdrobniałe sonetto - krótka riposta komunikująca bezpośrednią postawę wobec otoczenia.

Można to zauważyć już w sycylijskiej kolebce tej formy, u Giacoma da Lentiniego. Czuć w jego wierszach nutę elegancji, lecz wyrażana w nich miłość nie ma charakteru dworskiego. François Jost widzi w tym wpływy perspektywy arabskiej, innej niż w wypadku poetów prowansalskich:

Miłość poety arabskiego, jak również poety sycylijskiego podążającego arabskim tropem, nie jest prawie w ogóle typową miłością dworską, ponieważ zwykle nie bierze za swój obiekt żony, siostry lub córki miejscowego seniora, ani nawet żadnej wysoko urodzonej damy. Ci poeci obierają sobie kobiety o niepewnym pochodzeniu lub córki mieszczan. Źródłem natchnienia, znacznie większym niż tytuły odziedziczone po ojcach, stają się czar i piękno. Dla trubadura genealogia rodowa stanowiła poręczenie wdzięku. Arabowie, tak jak Sycylijczycy z ich szkoły, budują swoje uczucia bardziej na indywidualnych cechach ukochanej osoby niż na jej pozycji społecznej lub na innych konwenansach. W ten sposób Arabem czyli Sycylijczykiem jest Petrarca: on w ogóle nie zajmuje się stanem społecznym Laury, którą pewnego kwietniowego dnia 1327 roku zobaczył w kościele w Awinionie i którą potem opiewał przez całe swe $\dot{z ̇ y c i e}^{38}$.

Jostowi zdaje się wtórować Thomas Borgstedt, który zauważa, iż omawiany gatunek -

wyraźnie tematyzuje in ny rodzaj miłości, bez mitycznego ubóstwienia i bez osobistej służby. W kontekście intertekstualnym sonet wyodrębnia się swoją formalną i dyskursywną specyfika jako inny typ wiersza i właśnie dzięki temu może być nośnikiem innego podejścia, innej ideologii ${ }^{39}$.

Badacze wiążą te cechy po części z klasą społeczną reprezentowaną przez pierwszych sonecistów. Walter Mönch podkreślał: „To prawnicy i notariusze, a nie zawodowi poeci, trubadurzy czy minnesingerzy, wymyślili i pielęgnowali sonet na dworze cesarza Fryderyka II. To było znaczące" ${ }^{40}$. Ow sycylijski dwór niemieckiej dynastii Hohenstaufów stanowił „miejsce zmieszania cywilizacji śródziemnomorskich, szczególnie romańskich i arabskich, którym być może udzielił także niewielkiej domieszki własnej, nordyckiej krwi”"11. Kompozycyjna sprzeczność sonetu, który wchłonął prostą ludową formę 8-wersowego strambotto, dodając do niej wymagającą wirtuozerii 6-wersową część drugą, była w tej sytuacji formalnym zobrazowaniem świata, w jakim się narodził: „wieczernika literatury bez granic, którego członkowie wyróż-

Zob. Dzia de k, op. cit., s. 85-86.

F. J o s t, Le Sonnet de Pétrarque à Baudelaire. Modes et modulations. Berne 1989, s. 22.

Th. Borgstedt, Topik des Sonetts. Gattungstheorie und Gattungsgeschichte. Tübingen 2009, s. 110 .

Mön ch, op. cit., s. 47.

J o s t, op. cit., s. 12. 
niali się duchem kosmopolityzmu karmionym wszelkiego rodzaju wpływami” ${ }^{42}$, co - z jednej strony - przesądziło o nadspodziewanej otwartości tematycznej gatun$\mathrm{ku}$, ale też - $\mathrm{z}$ drugiej - przynajmniej na jakiś czas zdeterminowało jego układ komunikacyjny. Jak zauważa Michael R. G. Spiller, jeszcze w poezji Guittonego z Arezzo „zakłada się dyskusję lub co najmniej interakcję z innym podmiotem, na którego mówca ma wywrzeć wpływ deklamacją swoich jęków"43.

Pisząc te słowa, nie chcemy unieważniać późniejszych przemian sonetu, choć trzeba przyznać, że były one - przynajmniej przez jakiś czas - skorelowane $z$ odsłanianiem i dookreślaniem jego podstawy ideowej. Dość wczesny związek z formą cykliczną zdaje się wynikać np. $\mathrm{z}$ otwierającej się dzięki niej możliwości prezentowania dynamiki ludzkiego życia:

kiedy w rękach Dantego, a następnie Petrarki, sonet zyskał zdolność ujmowania o n t o g e n e zy, a więc rozwoju osobowości, jej ciągłości i nieciągłości zarazem, będącego jednym z głównych tematów literatury od czasów Wyznań św. Augustyna, cy kl sonetowy dopracował się nowego wymiaru. Stanowi on jedna $z$ nielicznych form literackich, które potrafią przedstawiać fragmentaryczny i bezpośredni charakter realnego istnienia (każdy wiersz jest odrębny), a jednocześnie kontynuacyjną naturę ludzkiej tożsamości (wiersze tworzą cykl) ${ }^{44}$.

Możemy się zatem przekonać, że nawet konwencja będąca nieomal emblematycznym przykładem destylacji formy $z$ wszelkich założeń ideowych, w swojej kolebce skrystalizowała się jako gatunek służący - zapewne bezwiednie - do wyrażenia określonej wizji społeczeństwa i człowieka. Zagadnienie obrazu świata jako definicyjnego elementu gatunku literackiego powinno być przeto rozważane nie tylko na przykładzie tych zjawisk, które istnieją właśnie po to, by podtrzymywać pewien światopogląd (haiku, litania, sielanka), lecz także w odniesieniu do form, które - jak sonet - wydają się zrazu czystą igraszką artystyczną. One bowiem wzywają nas do poszukiwania przełomowych momentów historycznych, w których dane konwencje - $\mathrm{u}$ zarania motywowane konkretnymi przeświadczeniami na temat rzeczywistości - płowiejąc z pierwotnych założeń, traciły status gatunku, by od tej pory funkcjonować w postaci semantycznie zredukowanej, np. jako „kanonizowany układ stroficzny wypowiedzi poetyckiej” ${ }^{\prime 5}$.

\author{
Abstract \\ WITOLD SADOWSKI University of Warsaw \\ ORCID: 0000-0002-9816-0111
}

\title{
GENERIC WORLDVIEWS: IDYLL, LITANY, SONNET
}

In this essay the term "worldview" is understood, according to German tradition, both as a Weltbild, or 'world picture,' and Lebensanschauung, or 'outlook on life'. The article describes the analogies between

Ibidem, s. 13.

M. R. G. S pill e r, The Development of the Sonnet: An Introduction. London - New York 1992, s. 35. Ibidem, s. 41.

Nazwa, którą J. Sławiński określa sonet (hasło w: M. Głowiński, T. Kostkiewiczowa, A. Okopień-Sławińska, J. Sławiński, Słownik terminów literackich. Red. J. Sławińs ki. Wyd. 2, popr. i uzup. Wrocław 1998, s. 517). 
generic worldview and linguistic worldview, taking into account their two properties, namely formal conservatism, and selectivity. Subsequently, genres whose worldviews expand beyond the level of linguistic expressibility are discussed on the example of the idyll and litany, i.e. poetic conventions which inspired their own painting and musical traditions. The article concludes with considerations on the sonnet as a convention that, nowadays, is regarded as emblematic for the lack of ideological commitment. However, as the author of the paper argues, in the initial period, the sonnet might have also been equipped with its own generic worldview. 